\title{
PENERAPAN METODE PARTICLE SWARM OPTIMIZATION (PSO) DAN GENETIC ALGORITHM (GA) PADA SISTEM OPTIMASI VISIBLE LIGHT COMMUNICATION (VLC) UNTUK MENENTUKAN POSISI ROBOT
}

\author{
Nanda Febri Istighfarin \\ Program Studi Teknik Elektro \\ Universitas Pertamina \\ Email: nandafebri.work@gmail.com \\ Regina Anisa Rahmastati \\ Program Studi Teknik Elektro \\ Universitas Pertamina \\ Email: reginaanisar@gmail.com \\ Herminarto Nugroho \\ Program Studi Teknik Elektro \\ Universitas Pertamina \\ Email: herminarto.nugroho@gmail.com
}

\begin{abstract}
ABSTRAK
Visible Light Communication (VLC) adalah suatu teknologi komunikasi yang memanfaatkan pancaran cahaya tampak untuk pengiriman dan penerimaan sinyal. Perkembangan VLC merupakan sebuah inovasi dalam sistem navigasi untuk melacak posisi dari sebuah objek dengan komunikasi cahaya tampak LED. LED digunakan untuk menentukan titik koordinat dari sebuah objek. Pada penelitian ini digunakan metode Particle Swarm Optimization (PSO) dan Genetic Algorithm (GA) untuk menentukan posisi robot terhadap posisi LED. Dari dua metode tersebut dapat diketahui keefisienan masing-masing metode serta mengetahui tingkat keakuratan posisi robot dalam menerima informasi data dari LED. Hasil analisis menunjukan jika nilai path loss yang diterima receiver semakin besar, maka nilai squared error semakin besar pula. Saat nilai squared error semakin besar, tingkat keakuratan penentuan posisi robot semakin kecil karena posisi robot semakin jauh dari titik referensi yaitu posisi LED. Dengan menggunakan metode PSO dan GA diketahui jika hasil pencarian nilai minimum error relatif sama baiknya. Perbedaan pada kedua metode terlihat pada proses komputasi, yaitu waktu komputasi serta banyaknya partikel atau generasi yang dihitung.
\end{abstract}

Kata Kunci: visible light communication; particle swarm optimization; genetic algorithm.

\section{ABSTRACT}

Visible Light Communication (VLC) is a communication technology that utilizes visible light beam for signal transmission and reception. VLC development is an innovation in navigation system to determine the position of an object by using the visible light communication of LED. LED is used for determining the coordinate point of an object. In this research, Particle Swarm Optimization (PSO) and Genetic Algorithm (GA) method are used to determine the position of the robot to the position of LED. From the two methods, the efficiency of each method and the level of accuracy of the position of the robot in receiving information from the LED can be determined. The results of the analysis showed if the value of the path loss of the receiver getting bigger, the squared error also comes bigger. When the value of the squared error is bigger, the accuracy of determining the robot position is getting smaller because the robot position farther from the reference point, which is known as LED position. By using the PSO and GA method, both methods have the good result of the minimum squared error value. The difference of the two method is the computation process, which is the computation time and the number of particle and generation calculated.

Keywords: visible light communication; particle swarm optimization; genetic algorithm.

\section{PENDAHULUAN}

Bidang ilmu pengetahuan dan teknologi mengalami kemajuan yang cukup pesat seiring dengan berkembangnya zaman. Perkembangan ilmu pengetahuan dan teknologi memungkinkan banyaknya sistem otomasi pada kehidupan sehari-hari. Banyaknya aplikasi sistem otomasi pada kehidupan sehari-hari 
mendorong manusia untuk menggunakan robot pada beberapa alat. Robot yang digunakan pada sebuah sistem pun harus diatur sedemikian rupa sehingga sesuai dengan keinginan pengguna. Salah satu variabel yang harus diketahui dalam pengaturan robot pada sebuah sistem adalah posisi robot.

Salah satu inovasi dalam menentukan posisi robot adalah penggunaan cahaya tampak (visible light) sebagai pembawa informasi atau juga dikenal dengan Visible Light Communication (VLC). VLC merupakan suatu teknologi komunikasi yang memanfaatkan pancaran cahaya tampak untuk pengiriman dan penerimaan informasi atau data [1]. Selain VLC, pengiriman dan penerimaan data dapat menggunakan global positioning system (GPS) [2]. Namun, penggunaan GPS pada robot mobile masih kurang efektif jika digunakan di dalam ruangan dan memiliki tingkat keakuratan yang kurang presisi saat terhalang oleh suatu objek [3]. Salah satu alternatif untuk mengatasi kekurangan tersebut yaitu dengan pengembangan VLC dengan komunikasi cahaya tampak LED.

Cahaya tampak yang berasal dari LED memiliki peluang untuk menghasilkan iluminasi yang simultan dan dapat dipakai dalam komunikasi data [4]. Pemanfaatan cahaya tampak dari LED dapat mengefisienkan pengiriman dan penerimaan sebuah data. Selain itu, VLC juga dapat meningkatkan pemanfaatan penggunaan LED. Hal ini merujuk pada penggunaan LED yang tidak hanya dijadikan sebagai penerangan saja namun dapat menjadi media komunikasi.

Selain itu, penentuan metode yang digunakan pada VLC juga menentukan kekuratan sistem dalam menentukan posisi sebuah robot. Perancangan VLC pada penelitian ini akan menggunakan dua metode optimasi, yaitu metode Particle Swarm Optimization (PSO) dan Genetic Algorithm (GA). Berdasarkan dua metode tersebut dapat diketahui keefisienan dari masing-masing metode dengan mengetahui tingkat keakuratan posisi robot dalam menerima informasi data dari LED.

\subsection{Particle Swarm Optimization (PSO)}

Metode PSO merupakan teknik optimasi yang pencarian solusinya mengikuti perilaku sosial yang terjadi pada kehidupan populasi burung (flock of bird) dan populasi ikan (school of fish) dalam bertahan hidup [5]. Setiap populasi memiliki individu yang dapat mempengaruhi individu lainya. Masing-masing individu tersebut merupakan partikel yang diibaratkan seperti sebuah titik ada suatu dimensi ruang waktu tertentu [6]. Misal pada sekelompok burung yang bermigrasi dari satu tempat ke tempat lain. Sekelompok burung cenderung akan membentuk sebuah formasi karena tiap burung yang bertetangga memiliki informasi jarak antar satu sama lain. Hal yang sama juga berlaku pada sekumpulan ikan yang bermigrasi. Ikan dapat mengetahui jarak antar satu sama lain karena bantuan gelombang air. Hal ini mengakibatkan ikan dapat bergerak dengan cepat dan jarak yang akurat dalam sebuah kelompok.

Metode PSO digunakan untuk mencari posisi dengan pengembalian nilai fungsi minimal dan teknik optimasinya yaitu dengan iterasi sampel dengan menggunakan titik acuan kualitas [5]. Pencarian solusi algoritma PSO dilakukan secara acak dari suatu populasi, dimana setiap partikel memiliki dua karakteristik yaitu posisi dan kecepatan [7]. Setiap partikel bergerak dalam ruang atau space tertentu kemudian mencari posisi terbaik yang dilaluinya dengan memperbaharui posisinya. Masing-masing partikel menyampaikan informasi posisi terbaik ke partikel lain dan menyesuaikan posisi dan kecepatan berdasarkan informasi posisi terbaik yang diterima.

\subsection{Genetic Algorithm (GA)}

Metode GA merupakan bagian dari Evolutionary Algorithm, yaitu algoritma yang mengikuti proses evolusi alami. Konsep utama dari Evolutionary Algorithm adalah individu yang paling unggul akan bertahan hidup, sedangkan individu yang lemah akan punah. Oleh sebab itu, metode ini digunakan untuk menemukan solusi optimal pada masalah komputasi yang diberikan. Solusi optimal yang didapatkan oleh GA didapatkan dengan cara memaksimalkan atau meminimalkan fungsi tertentu [8].

Pencarian solusi algoritma GA diawali dengan menentukan populasi awal. Populasi awal terdiri dari himpunan solusi yang dihasilkan secara acak. Setiap individu yang berada dalam populasi disebut kromosom, yang merupakan representasi dari kandidat-kandidat solusi. Setiap kromosom kemudian dievaluasi tingkat ketangguhanya (fitness) oleh fungsi yang telah ditentukan. Setelah itu akan dilakukan seleksi alam gen dari dua kromosom (parent). Seleksi alam akan menghasilkan kromoson baru dengan fitness yang lebih tinggi sebagai generasi baru (offspiring). Kromosom tersebut akan mengalami iterasi yang disebut generasi. Setiap generasi kromosom dievaluasi berdasarkan nilai fungsi fitness. Setelah melalui beberapa generasi, maka GA akan mendapatkan kromosom terbaik yang merupakan solusi optimal [9]. 


\section{METODE PENELITIAN}

Simulasi dilakukan pada sebuah ruangan dengan ukuran $24 \mathrm{~m} \times 24 \mathrm{~m}$ (luas $=576 \mathrm{~m}^{2}$ ). Pada rungan tersebut ketinggian LED ditentukan sebesar $12 \mathrm{~m}$ dari permukaan tanah. Skema ruangan yang disimulasikan dapat dilihat pada Gambar 1.

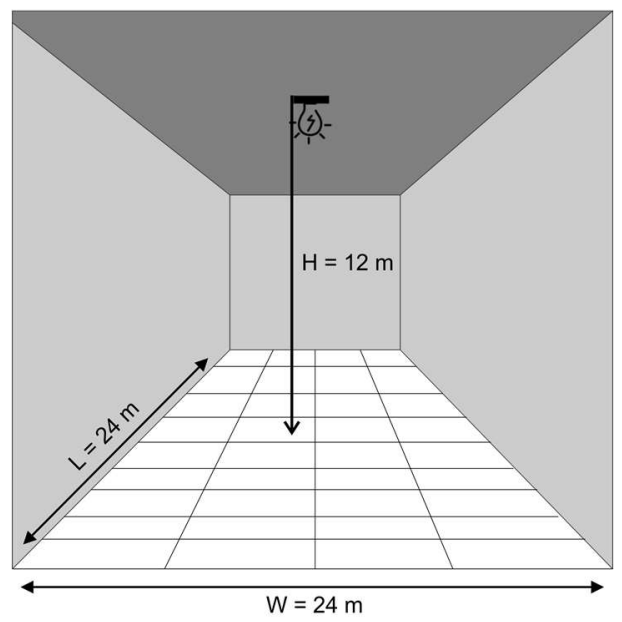

Gambar 1. Spesifikasi Ruangan yang Digunakan

Receiver pada robot yang disimulasikan merupakan sebuah photodetector. Adapun skematika pancaran daya dari LED pada ruangan hingga mencapai photodetector dapat dilihat pada Gambar 2.
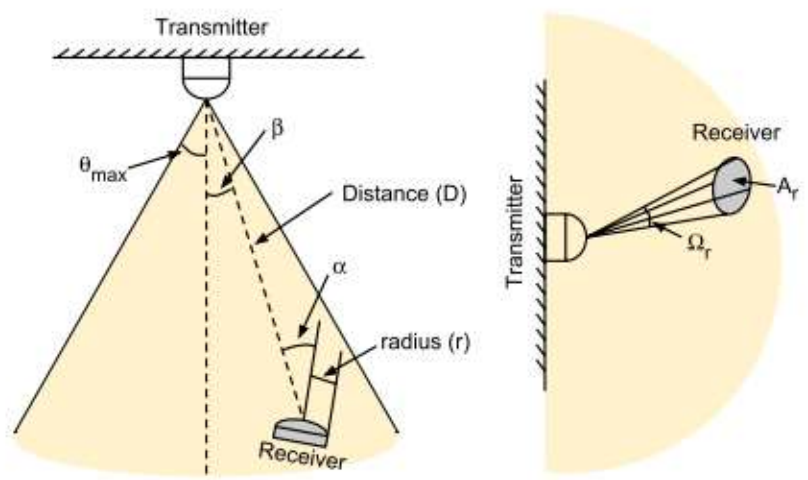

\section{Gambar 2. Posisi Relatif Transmitter (LED) terhadap Receiver (Photodetector) [1]}

Posisi yang tegak lurus dengan LED diasumsikan sebagai posisi acuan dalam penentuan posisi robot (R). Hal ini mengindikasikan jika posisi robot merupakan jarak dari titik acuan yang telah ditentukan. Melalui Gambar 2 posisi robot dapat ditentukan melalui Hukum Pythagoras berdasarkan variabel $\mathrm{H}$ yang mendefinisikan tinggi dari transmitter (LED) terhadap tanah, serta variabel D yang mendefinisikan posisi terhadap pancaran aktual LED yang diterima robot. Adapun penentuan posisi robot dapat dituliskan pada persamaan (1).

$$
R=\sqrt{D^{2}-H^{2}}
$$

Nilai D merupakan salah satu variabel yang mempengaruhi parameter path loss $\left(L_{L}\right)$ yang dipancarkan dari LED. Path loss merupakan parameter dimana daya yang diterima oleh receiver dari LED tidak mencapai nilai maksimum pancaran daya yang dapat dikeluarkan LED. Berdasarkan penelitian [1], perhitungan path loss LED dapat dituliskan menjadi persamaan (2).

$$
L_{L}=\frac{(m+1) A_{r}}{2 \pi D^{2}} \cos \alpha \cos ^{m} \beta
$$

Nilai $m$ merepresentasikan orde emisi Lambert yang dituliskan pada persamaan (3). 


$$
m=\frac{\ln (2)}{\ln \left(\cos \left(\phi_{1 / 2}\right)\right)^{\prime}}
$$

Pada persamaan (2) terdapat variabel $\beta$ yang dapat diketahui melalui Gambar 3.

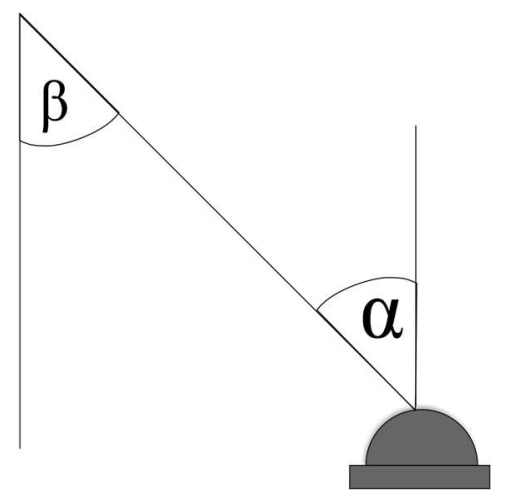

\section{Gambar 3. Sudut $\alpha$ dan $\beta$}

Berdasarkan Gambar 2 dan Gambar 3 dapat diketahui jika sudut $\alpha$ dan $\beta$ memiliki nilai yang sama. Oleh karena itu sudut $\alpha$ dan $\beta$ dapat dituliskan dalam fungsi D seperti persamaan (4).

$$
\cos \alpha=\cos \beta=\frac{H}{D}
$$

Adapun nilai dari $L_{L}$ juga dapat dituliskan dalam fungsi D seperti persamaan (5)

$$
L_{L}=\frac{(m+1) H \cdot A_{r}}{2 \pi D^{3}}\left(\frac{H}{D}\right)^{m}
$$

Dalam mencari tingkat keakuratan hasil penentuan posisi robot, maka pada penelitian ini digunakan parameter squared error seperti pada penelitian [1]. Apabila nilai squared error semakin kecil maka nilai dari jarak robot terhadap posisi referensi semakin akurat. Oleh karena itu dilakukan optimasi untuk mencari nilai minimum squared error yang dapat dituliskan pada persamaan (6).

$$
\min _{\mathrm{D}}\left(L_{L, \text { desired }}-L_{L, \text { actual }}\right)^{2}
$$

Nilai $L_{L, a c t u a l}$ pada persamaan (6) didapatkan dari persamaan (5), sedangkan nilai dari $L_{L, \text { desired }}$ merupakan nilai yang berkisar dari 0-1.

\subsection{Particle Swarm Optimization (PSO)}

Simulasi menggunakan metode PSO dilakukan pada MATLAB dengan pengaturan default dan fungsi objektif pada persamaan (6). Adapun terdapat batasan-batasan yang harus dipenuhi dalam mencapai nilai maksimal pada fungsi objektif berdasarkan spesifikasi ruangan yang telah ditentukan.

Asumsi nilai D minimum yang akan didapatkan adalah sebesar $12 \mathrm{~m}$. Hal ini dikarenakan robot berada tepat di bawah LED sehingga memiliki jarak sebesar tinggi ruangan. Kemudian asumsi nilai maksimum D sebesar 12 $\sqrt{2} \mathrm{~m}$ yang didapatkan dengan menggunakan Hukum Pythagoras pada persamaan (1). Pada perhitungan persamaan (1), nilai $\mathrm{H}$ tetap konstan dan nilai $\mathrm{R}$ dianggap maksimum sebesar $12 \mathrm{~m}$, yaitu setengah dari panjang ruangan yang diimulasikan.

Maka, secara lengkap fungsi objektif dalam pencarian nilai desain variabel D adalah sebagai berikut,

$$
\min _{\mathrm{D}}\left(L_{L, \text { desired }}-\frac{(m+1) H \cdot A_{r}}{2 \pi D^{3}}\left(\frac{H}{D}\right)^{m}\right)^{2} \quad \text { s.t } 12 \leq D \leq 12 \sqrt{2}
$$

Photodetector yang digunakan pada simulasi memiliki luas permukaan sebesar $\mathbf{1} \times \mathbf{1 0}^{\mathbf{- 4}} \mathbf{m}^{\mathbf{2}}$. Sedangkan nilai semi-angle phase dari LED memiliki nilai sebesar $\mathbf{7 0}^{\circ}$. Kemudian, kode pemrograman pada MATLAB dapat dituliskan sebagai berikut, 


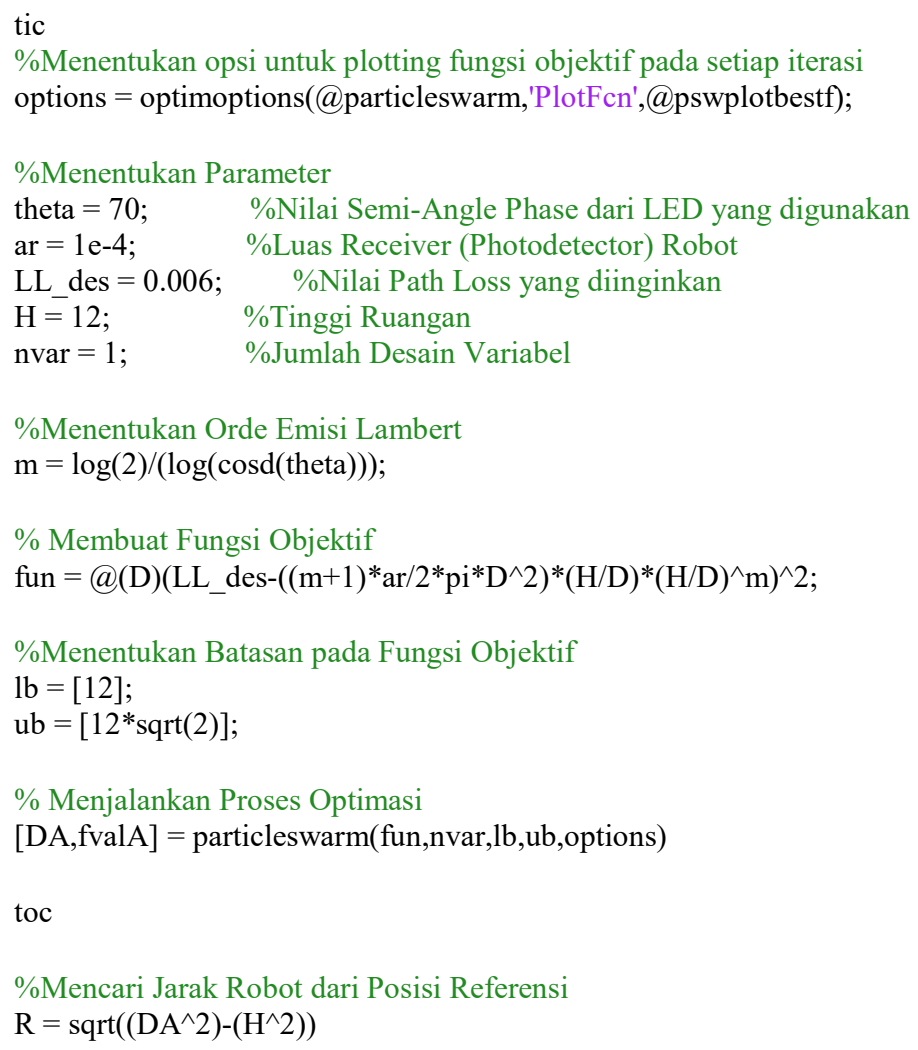

\subsection{Genetic Algorithm (GA)}

Simulasi dengan metode GA dilakukan pada MATLAB dengan pengaturan default dan menggunakan fungsi objektif pada persamaan (6). Adapun terdapat batasan-batasan yang harus dipenuhi dalam mencapai nilai maksimal pada fungsi objektif, berdasarkan spesifikasi ruangan yang telah ditentukan.

Asumsi nilai D minimum yang akan didapatkan adalah sebesar $12 \mathrm{~m}$. Hal ini dikarenakan robot berada tepat di bawah LED sehingga memiliki jarak sebesar tinggi ruangan. Kemudian asumsi nilai maksimum D sebesar $12 \sqrt{2} \mathrm{~m}$ yang didapatkan dengan menggunakan Hukum Pythagoras pada persamaan (1). Pada perhitungan persamaan (1), nilai $\mathrm{H}$ tetap konstan dan nilai $\mathrm{R}$ dianggap maksimum sebesar $12 \mathrm{~m}$, yaitu setengah dari panjang ruangan yang diimulasikan.

Maka, secara lengkap fungsi objektif dalam pencarian nilai desain variabel D adalah sebagai berikut,

$$
\min _{\mathrm{D}}\left(L_{L, \text { desired }}-\frac{(m+1) H \cdot A_{r}}{2 \pi D^{3}}\left(\frac{H}{D}\right)^{m}\right)^{2} \quad \text { s.t } 12 \leq D \leq 12 \sqrt{2}
$$

Photodetector yang digunakan pada simulasi memiliki luas permukaan sebesar $\mathbf{1} \times \mathbf{1 0}^{-\mathbf{4}} \mathbf{m}^{\mathbf{2}}$. Sedangkan nilai semi-angle phase dari LED memiliki nilai sebesar $\mathbf{7 0}^{\circ}$. Kemudian, kode pemrograman pada MATLAB dapat dituliskan sebagai berikut,

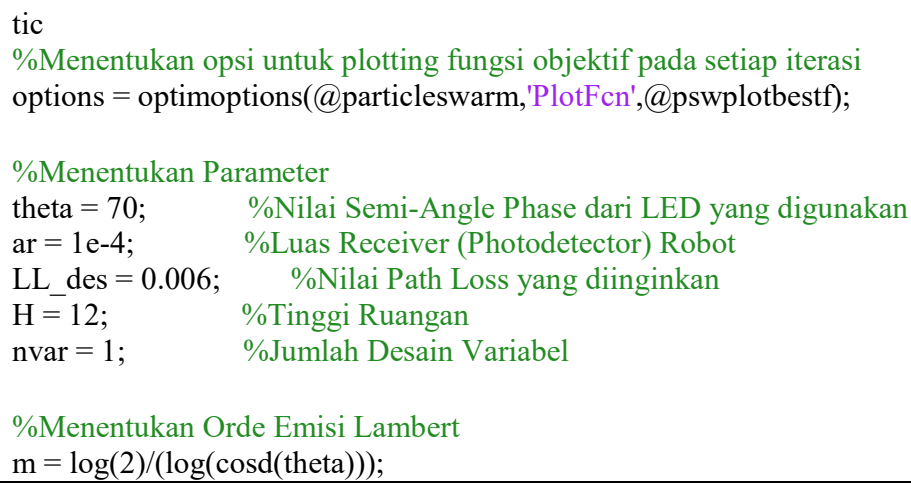




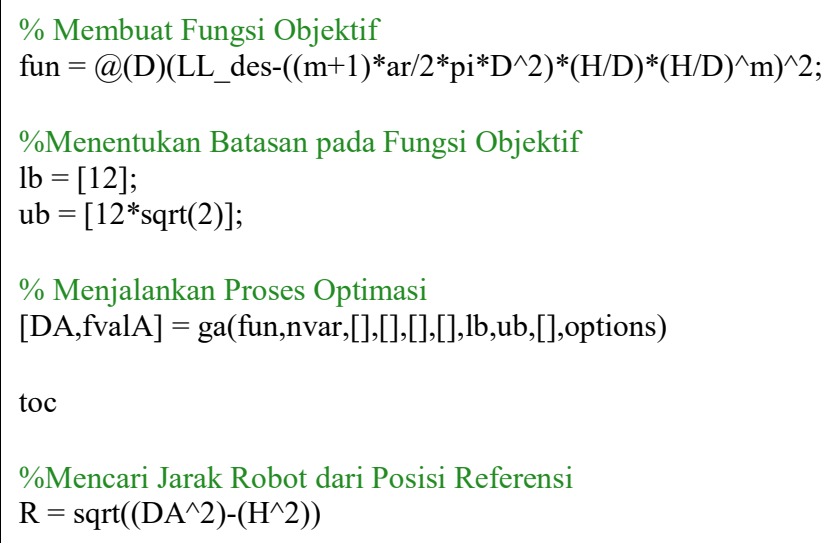

\section{HASIL DAN PEMBAHASAN}

Tingkat keakuratan penentuan posisi robot menggunakan metode PSO dan GA dilakukan dengan pencarian nilai minimum squared error pada masing-masing metode dengan variasi $L_{L, \text { desired }}$. Pada pengujian pertama digunakan metode PSO pengujian dengan lima nilai $L_{L, \text { desired }}$ yang berbeda. Adapun hasil pengujian menggunakan metode PSO dapat dilihat pada Tabel 1 dan Gambar 4.

Tabel 1. Hasil pengujian dengan metode PSO

\begin{tabular}{cccccc}
\hline \multirow{2}{*}{ No } & \multirow{2}{*}{$\boldsymbol{L}_{\boldsymbol{L}, \text { desired }}$} & $\boldsymbol{D}(\boldsymbol{m})$ & $\boldsymbol{R}(\boldsymbol{m})$ & Squared Error & Waktu Komputasi(s) \\
\cline { 3 - 6 } & 0,006 & 12 & 0 & $4,03 \mathrm{E}-06$ & 1,484118 \\
1 & 0,009 & 12,8767 & 4,67 & $5,31 \mathrm{E}-11$ & 1,70848 \\
2 & 0,01 & 13,7346 & 6,6813 & $1,58 \mathrm{E}-17$ & 1,323035 \\
3 & 0,4 & 16,9706 & 12 & 0,1489 & 1,466332 \\
4 & 1 & 16,9706 & 12 & 0,9719 & 1,447215 \\
5 & \multicolumn{5}{c}{ Rata-rata Waktu } \\
\hline
\end{tabular}

Keterangan:

$\mathrm{D}=$ Posisi terhadap pancaran aktual LED yang diterima robot $\mathrm{R}=$ Posisi robot yang tegak lurus terhadap LED

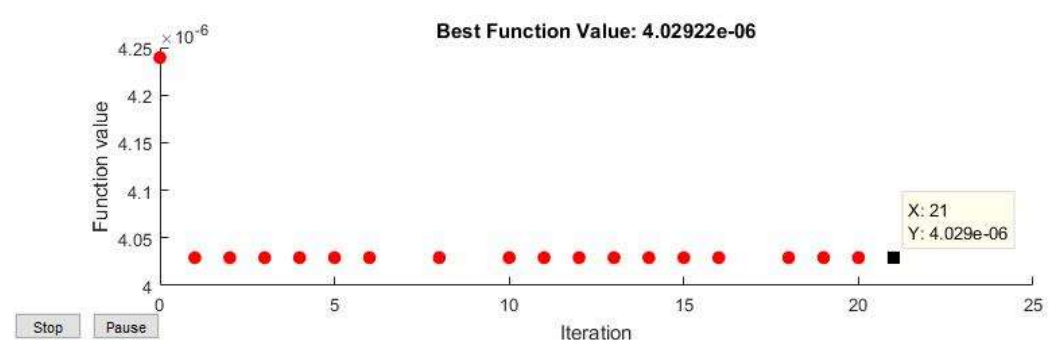

(a)

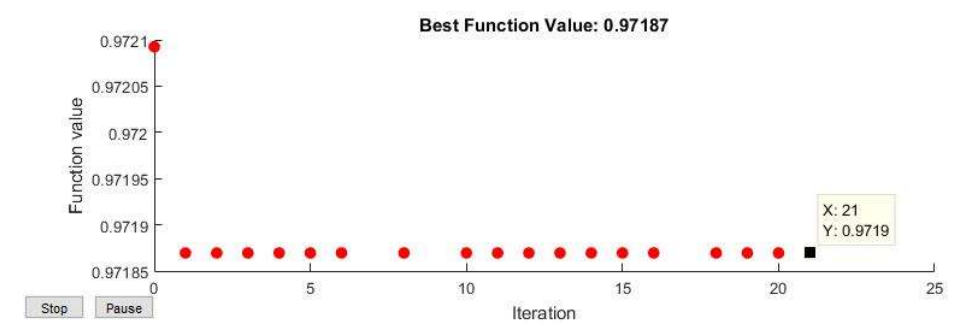

(b)

Gambar 4. Hasil Pencarian Nilai Squared Error pada Metode PSO dengan (a) $L_{L, \text { desired }}=0.006$ dan (b) $L_{L, \text { desired }}=1$ 
Berdasarkan Tabel 1 diketahui jika semakin besar nilai path loss $\left(L_{L, \text { desired }}\right)$ maka nilai posisi terhadap pancaran aktual LED yang diterima robot (D) akan semakin besar. Semakin besar nilai D, maka nilai posisi robot yang tegak lurus terhadap LED (R) juga semakin besar. Hal ini dikarenakan nilai R didapatkan dari persamaan (1) dengan nilai tinggi transmitter terhadap tanah $(\mathrm{H})$ selalu konstan. Apabila nilai D semakin besar sedangkan nilai $\mathrm{H}$ konstan, maka nilai $\mathrm{R}$ akan bertambah besar.

Nilai R yang besar mengindikasikan jika posisi robot semakin jauh dari titik referensi yang berada tepat di bawah LED. Namun, dapat dilihat pada Tabel 1, seiring dengan pertambahan nilai $L_{L, \text { desired }}$ maka nilai squared error semakin besar. Saat nilai squared error semakin besar maka tingkat keakuratan penentuan posisi robot semakin kecil karena semakin jauhnya posisi robot dari titik referensi yang berupa posisi LED.

Pada Gambar 4 dapat diketahui jika metode PSO dengan $L_{L \text {,desired }}$ yang berbeda memiliki jumlah komputasi yang sama, yaitu sebanyak 21 kali. Seluruh komputasi pada metode PSO dapat dilakukan dengan rata-rata waktu sebesar 1,485836 detik. Banyaknya partikel yang diproses pada metode PSO secara default pada MATLAB sebesar min(100, 10*nvar)dengan nilai nvar yang digunakan pada simulasi adalah 1 . Hal ini mengindikasikan jumlah partikel pada simulasi yang dilakukan adalah 10 partikel.

Pada percobaan kedua dilakukan pengujian dengan menggunakan metode GA dengan lima nilai $L_{L, \text { desired }}$ yang berbeda. Adapun hasil pengujian menggunakan metode GA dapat dilihat pada Tabel 2 dan Gambar 5.

Tabel 2. Hasil pengujian dengan metode GA

\begin{tabular}{cccccc}
\hline \multirow{2}{*}{ No } & \multirow{2}{*}{$L_{L, \text { desired }}$} & $\mathrm{D}(\mathrm{m})$ & $\mathrm{R}(\mathrm{m})$ & Squared Error & Waktu Komputasi $(\mathrm{s})$ \\
\cline { 3 - 6 } & 0,006 & 12 & 0 & $4,03 \mathrm{E}-06$ & 3,547342 \\
1 & 0,009 & 12,883 & 4,6874 & $1,28 \mathrm{E}-16$ & 3,568643 \\
2 & 0,01 & 13,7347 & 6,6814 & $4,46 \mathrm{E}-15$ & 4,028039 \\
3 & 0,4 & 16,9706 & 12 & 0,1489 & 3,425379 \\
4 & 1 & 16,9706 & 12 & 0,9719 & 3,041352 \\
5 & \multicolumn{5}{c}{ Rata-rata Waktu } \\
\hline
\end{tabular}

Keterangan:

$\mathrm{D}=$ Posisi terhadap pancaran aktual LED yang diterima robot

$\mathrm{R}=$ Posisi robot yang tegak lurus terhadap LED

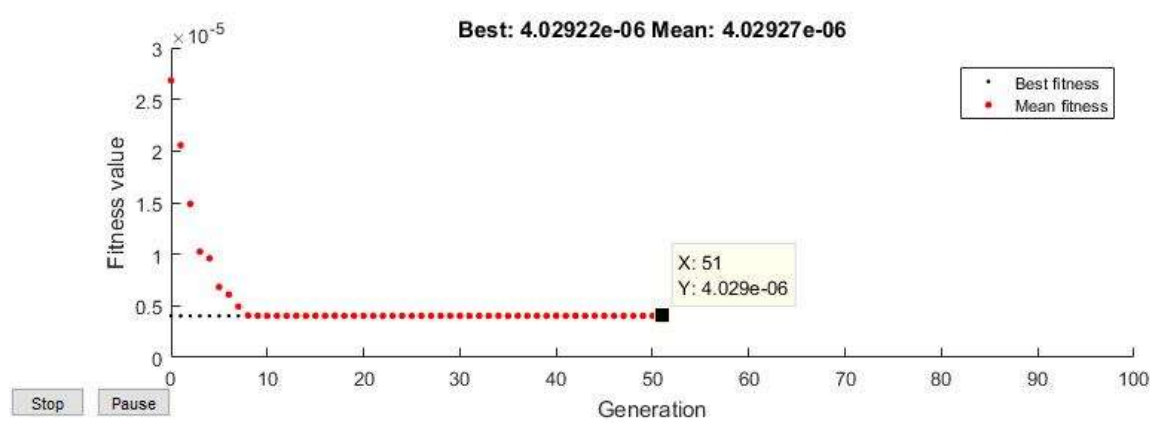

(a)

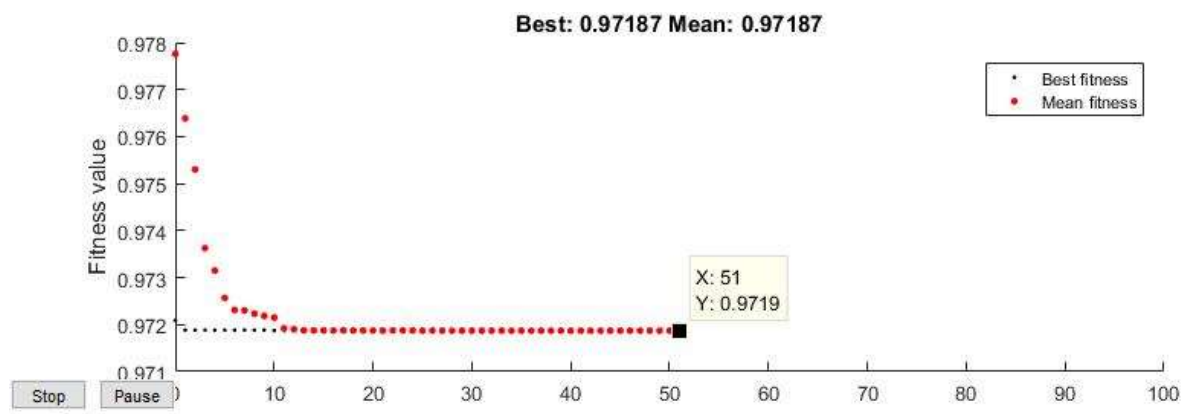

(b)

Gambar 5. Hasil Pencarian Nilai Squared Error pada Metode GA dengan (a) $L_{L, \text { desired }}=0.006$ dan (b) $L_{L, \text { desired }}=1$ 
Berdasarkan Tabel 2 diketahui jika semakin besar nilai path loss $\left(L_{L, d e s i r e d}\right)$ maka nilai posisi terhadap pancaran aktual LED yang diterima robot (D) akan semakin besar. Semakin besar nilai D, maka nilai posisi robot yang tegak lurus terhadap LED (R) juga semakin besar. Hal ini dikarenakan nilai R didapatkan dari persamaan (1) dengan nilai tinggi transmitter terhadap tanah (H) selalu konstan. Apabila nilai D semakin besar sedangkan nilai $\mathrm{H}$ konstan, maka nilai $\mathrm{R}$ akan bertambah besar.

Nilai R yang besar mengindikasikan jika posisi robot semakin jauh dari titik referensi yang berada tepat di bawah LED. Namun, dapat dilihat pada Tabel 2, seiring dengan pertambahan nilai $L_{L, \text { desired }}$ maka nilai squared error semakin besar. Saat nilai squared error semakin besar maka tingkat keakuratan penentuan posisi robot semakin kecil karena semakin jauhnya posisi robot dari titik referensi yang berupa posisi LED.

Pada Gambar 5 dapat diketahui jika metode GA dengan $L_{L \text {,desired }}$ yang berbeda memiliki jumlah komputasi sebanyak 51 kali. Seluruh komputasi pada metode GA dapat dilakukan dengan rata-rata waktu sebesar 3,522151 detik. Banyaknya generasi yang diproses pada metode GA secara default pada MATLAB sebesar $100 *$ nvar dimana nilai nvar yang digunakan pada simulasi adalah 1 . Hal ini mengindikasikan jumlah generasi pada simulasi yang dilakukan adalah 100 generasi.

\section{KESIMPULAN}

Pada pengujian metode PSO dan GA, keefisienan masing-masing metode diketahui melalui tingkat keakuratan posisi robot dalam menerima informasi data dari LED. Berdasarkan hasil dan pembahasan dari kedua simulasi metode yang telah dilakukan, dapat diketahui jika hasil pencarian nilai minimum squared error memiliki nilai yang relatif sama baiknya. Perbedaan terlihat pada proses komputasi yang dilakukan oleh kedua metode. Pada metode PSO dengan jumlah partikel sebanyak 10, program secara otomatis melakukan 21 kali komputasi dengan rata-rata waktu sebesar 1,485836 detik. Sedangkan pada metode GA dengan jumlah generasi sebanyak 100, program secara otomatis melakukan 51 kali komputasi dengan ratarata waktu sebesar 3,522151 detik. Berdasarkan hasil percobaan tersebut, maka dapat disimpulkan jika metode PSO lebih unggul dibandingkan dengan metode GA. Hal ini dikarenakan dengan hasil squared error yang sama, metode PSO dapat melakukan komputasi lebih sedikit dan dengan waktu yang relatif lebih cepat.

\section{DAFTAR PUSTAKA}

[1] P. H. Pathak, X. Feng, P. Hu, and P. Mohapatra, "Visible Light Communication, Networking, and Sensing: A Survey, Potential and Challenges," IEEE Communications Surveys and Tutorials. 2015, doi: 10.1109/COMST.2015.2476474.

[2] L. M. Varalakshmi and R. Ramalingam, "GPS-based Navigated Autonomous Robot," Int. J. Emerg. Trends Eng. Res., vol. 3, no. 4, pp. 8-13, 2015.

[3] Auto Alert, "Potential Problems with GPS Tracking," 2015, [Online]. Available: https://www.autoalert.me.uk/problems-with-gps-tracking/.

[4] D. C. O'Brien, L. Zeng, H. Le-Minh, G. Faulkner, J. W. Walewski, and S. Randel, "Visible Light Communications: Challenges and possibilities," in IEEE International Symposium on Personal, Indoor and Mobile Radio Communications, PIMRC, 2008, doi: 10.1109/PIMRC.2008.4699964.

[5] A. Rosita and Y. Purwananto, "Implementasi Algoritma Particle Swarm untuk Menyelesaikan Sistem Persamaan Nonlinear," J. Tek. ITS Vol. 1, (Sept, 2012), 2012.

[6] M. Mansur, T. Prahasto, and F. Farikhin, "Particle Swarm Optimization Untuk Sistem Informasi Penjadwalan Resource Di Perguruan Tinggi," J. Sist. Inf. BISNIS, vol. 4, 2014, doi: 10.21456/vol4iss1pp11-19.

[7] D. F. Shiau, "A hybrid particle swarm optimization for a university course scheduling problem with flexible preferences," Expert Syst. Appl., 2011, doi: 10.1016/j.eswa.2010.06.051.

[8] J. Carr, "An Introduction to Genetic Algorithms," pp. 1-40, 2014, [Online]. Available: http://www.javamath.com/snucode/lecture.pdf.

[9] L. Rohaeni, D. Saepudin, and A. A. Rohmawati, "Penerapan Algoritma Genetika Untuk Optimasi Debit Air Pada Pembangkit Listrik Tenaga Air 'Studi Kasus: Waduk Situ Cileunca, Jawa Barat,"” in $e$ Proceeding of Engineering, 2016. 